\title{
Adhesion of endothelial cells and adsorption of serum proteins on gas plasma-treated polytetrafluoroethylene
}

\author{
A. Dekker, K. Reitsma, T. Beugeling, A. Bantjes, J. Feijen and W.G. van Aken \\ University of Twente, Faculty of Chemical Yechnology, PO Box 217, 7500 AE Enschede, The Netherlands \\ Presented at Biointeractions '90, Oxford, UK, 21-23 August 1990
}

\begin{abstract}
From in vitro experiments it is known that human endothelial cells show poor adhesion to hydrophobic polymers. The hydrophobicity of vascular prostheses manufactured from Teflon ${ }^{\circledR}$ or Decron ${ }^{\circledR}$ may be the reason why endothelialization of these grafts does not occur after implantation in humans. We modified films of polytetrafluoroethylene (Teflon ${ }^{\circledR}$ ) by nitrogen plasma and oxygen plasma treatments to make the surfaces more hydrophilic. Depending on the plasma exposure time, modified polytetrafluoroethylene surfaces showed water-contact angles of $15-58^{\circ}$, versus $96^{\circ}$ for unmodified polytetrafluoroethylene. ESCA measurements revealed incorporation of both nitrogen- and oxygen-containing groups into the polytetrafluoroethylene surfaces, dependent on the plasma composition and exposure time. The thickness of the modified surface layer was $\sim 1 \mathrm{~nm}$. The adhesion of cultured human endothelial cells from $20 \%$ human serum-containing culture medium to modified polytetrafluoroethylene surfaces with contact angles of $20-45^{\circ}$ led to the formation of a monolayer of cells, which was similar to the one formed on tissue culture polystyrene, the reference surface. This was not the case when endothelial cells were seeded upon unmodified polytetrafluoroethylene. Surface-modified expanded polytetrafluoroethylene prosthesis material (GORE TEX ${ }^{\circledR}$ soft tissue) also showed adhesion of endothelial cells comparahle to cell adhesion to the reference surface. The amounts of serum proteins, including fibronectin, adsorbed from serumcontaining medium to modified polytetrafluoroethylene surfaces were larger than those adsorbed to unmodified polytetrafluoroethylene. Moreover, the modified surfaces probably allow the exchange of adsorbed serum proteins with cellular fibronectin.
\end{abstract}

Keywords: Polytetrafluoroethylene, human endothelial cells, gas plasma

\begin{abstract}
Synthetic vascular grafts with a relatively large inner diameter (>5 mm) are successfully employed for replacement or bypassing of stenosed or obstructed arteries ${ }^{1}$. However, the use of small-diameter vascular grafts is limited, because these grafts rapidly occlude due to thrombosis ${ }^{1}$. The ideal blood-contacting surface of a prosthesis would be an endothelial lining, because endothelium is the natural non-thrombogenic lining of blood vessels ${ }^{2}$. Since in humans endothelium does not develop spontaneously on the luminal side of a graft, seeding of autologous endothelial cells during surgery will be necessary ${ }^{1-3}$. In both dogs ${ }^{4}$ and humans ${ }^{5,6}$, it has been shown that seeding of vascular prostheses with endothelial cells decreases platelet deposition onto the graft and improves the patency. Improved patency, accompanied by an increased coverage with endothelial cells, has been observed in dogs using seeded Dacron ${ }^{\circledR}$ (poly(ethylene terephthalate) (PET) prostheses ${ }^{4,7,8}$ as well as seeded expanded Teflon ${ }^{\circledR}$ (polytetrafluoroethylene; (ePTFE)) grafts ${ }^{7-9}$.
\end{abstract}

Correspondence to Dr T. Beugeling
Optimal interaction of endothelial cells with the graft surface is necessary for cell overgrowth. Results of in vitro studies in our laboratory on the interactions of human endothelial cells with polymers revealed that endothelial cells show poor adhesion to hydrophobic materials (e.g. PET) and optimal adhesion to moderately water-wettable polymers ${ }^{10}$. PET vascular grafts before cell seeding are normally preclotted, which prevents leakage of the grafts and provides a substrate suitable for cell adhesion ${ }^{7-9}$. ePTFE prostheses are also preclotted for the latter reason. Alternatively, a fibronectin coating of the luminal surface has been used to improve endothelial cell-graft interaction ${ }^{11,12}$. However, this coating stimulates platelet deposition onto those parts of the surface not covered with endothelial cells ${ }^{12-15}$. An alternative method for making the luminal side of a prosthesis more suitable for endothelial cell overgrowth is to increase the wettability of the surface ${ }^{10}$.

In the present study, this concept was applied to polytetrafluoroethylene (PTFE) films and to ePTFE graft material. PTFE surfaces were modified by gas plasma (glow

(C) 1991 Buttenworth-Heinemann Ltd. 0142-9612/91/020130-09 
discharge) treatment which made them more wettable. The effect of this treatment on the surface composition. surface charge, adsorption of serum proteins and adhesion of human endothelial cells was investigated.

\section{MATERIALS AND METHODS}

\section{Plasma treatment}

PTFE films $(13 \mathrm{~cm} \times 13 \mathrm{~cm} \times 100 \mu \mathrm{m}$; Fluorplast Nederland BV., Raamsdonksveer, The Netherlands) were cleaned ultrasonically for $30 \mathrm{~min}$ in a $1 \%(\mathrm{v} / \mathrm{v})$ detergent solution (RBS 25, Hicol, Oud-Beierland, The Netherlands) and extensively rinsed with distilled water and absolute ethanol (Merck, Darmstadt, Germany). Expanded PTFE patch (soft tissue, GORETEX ${ }^{(}$, W.L. Gore and Associates, Flagstaff, AZ, USA) was used as received.

The gas plasma (glow discharge) treatment was performed in a Plasmafab 505 barrel plasma reactor (Elecrotech, Bristol, UK). The PTFE surfaces were placed $25 \mathrm{~mm}$ above the inner electrode, immediately above the position of the generated plasma. The gases used were oxygen (>99.5\% ( $\mathrm{v} / \mathrm{v}$ ); Hoekloos, Schiedam. The Netherlands) and nitrogen ( $>99.9990 \%(v / v)$; Hoekloos, Schiedom, The Netherlands). The pressure inside the plasma chamber was kept at $20 \pm 1 \mathrm{~Pa}$ for the ritrogen plasma and at $9 \pm 1$ $\mathrm{Pa}$ for the oxygen plasma. The electrode power unless otherwise mentioned was $250 \mathrm{~W}$ for the nitrogen plasma and $300 \mathrm{~W}$ for the oxygen plasma. The gas flow of both gases was chosen in such a way that the above mentioned plasma pressures were realized.

The plasma treatment consisted of three steps. First, the PTFE surfaces were degassed for $1 \mathrm{~min}$ at $<1 \mathrm{~Pa}$. Second, the plasma was generated for the desired time. Third, the plasma chamber was flushed for $5 \mathrm{~min}$ with the same gas at the same pressure. Atmospheric pressure in the plasma chamber was restored by flushing with argon (>99.997\% ( $/ / v)$; Hoekloos, Schiedam, The Netherlands). The treated PTFE samples were stored in hyperfiltrated water at room temperature before being used for experiments.

\section{Contact angle measurement}

Contact angles were determined by means of the captive bubble method ${ }^{16}, 20-24 \mathrm{~h}$ after plasma treatment. The contact angle $(\theta)$ was calculated from the height $(h)$ and the width $(b)$ of the air bubble at the polymer surface:

$$
\theta=180^{\circ}-2 \arctan (2 h / b)
$$

All contact angles are expressed as the mean of three determinations of the same film ( \pm standard deviation).

\section{Zeta potential}

The zeta potentials of the polymer surfaces were determined from streaming potential measurements in a flat plate system $^{17,18}$. The composition of the streaming electrolyte solution was: $0.01 \mathrm{M} \mathrm{KCl}, 8.10^{4} \mathrm{M} \mathrm{Na}_{2} \mathrm{HPO}_{4}, 2.10^{4} \mathrm{M}$ $\mathrm{KH}_{2} \mathrm{PO}_{4} ; \mathrm{pH}$ 7.4. The zeta potential $\left(\psi_{\zeta}\right)$ was calculated from:

$$
\psi_{\varsigma}=8.4922 \cdot 10^{-8} \cdot\left(\Delta E_{\mathrm{str}} / \Delta P\right) \cdot\left(K_{\mathrm{B}} \cdot \eta / \varepsilon\right)
$$

wherein $\Delta E_{\mathrm{str}}$ is the streaming potential, $\Delta P$ is the pressure difference, $K_{\mathrm{B}}$ is the specific conductivity of bulk electrolyte, $\eta(1.0 \mathrm{mPa}$.s $)$ is the electrolyte viscosity and $\varepsilon(=80.14)$ is the dielectric constant ${ }^{18}$.

\section{ESCA}

ESCA measurements were performed with a Kratos XSAM 800 (Kratos Analytical, Manchester, UK). For etching surfaces, the system was equipped with a differential pumped microbeam argon ion gun. All polymer samples were dried for at least 1 wk in a bell jar, kept in vacuum with a zeolite vacuum pump. ESCA measurements of the PTFE films were performed with $X$-rays from a $\mathrm{Mg}$ source $(1253.6 \mathrm{eV})$ at a take-off angle of $30^{\circ}$ between the polymer surface and the analyser. For quantitative analysis, detail scans (steps $0.05 \mathrm{eV}$ ) were made of the C1s, F1s, $01 \mathrm{~s}$ and $\mathrm{N} 1 \mathrm{~s}$ peaks, at medium resolution ( $20 \mathrm{eV}$ pass energy) and low magnification $\left(0.75 \mathrm{~cm}^{2}\right.$ spot size). Integration of the peaks, calculation of the surface concentration of the various elements, and $X$-ray satellite subtraction were performed with standard software (DS 800) supplied by the manufacturer. Using this ESCA spectrometer, it is not possible to compare the calculated surface concentrations of the different elements with each other if the detail spectra are made at medium resolution; only the surface concentrations of oxygen and nitrogen in plasma-treated PTFE films were calculated relative to the concentrations of these elements in films, which were treated for $600 \mathrm{~s}$. PTFE samples, treated for $600 \mathrm{~s}$ with nitrogen or oxygen plasma, were etched for depth profiling with $\mathrm{Ar}^{+}$ions at a rate corresponding to $0.5 \mathrm{~nm} / \mathrm{min}$ for $\mathrm{Ta}_{2} \mathrm{O}_{5}$.

\section{Protein adsorption}

The adsorption of human serum albumin (HSA), human fibronectin (Fn), human immunoglobulin $\mathrm{G}(\mathrm{lg} G)$ and human high-density lipoprotein (HDL) to unmodified and plasmatreated PTFE films from 20\% human serum-containing culture medium was detected by means of a two step enzyme immunoassay (EIA) as described by van Wachem et al. ${ }^{19}$. Polyclonal antibodies directed against HSA, Fn and IgG were obtained from the Central Laboratory of The Netherlands Red Cross Blood Transfusion Service (CLB, Amsterdam, The Netherlands) and the antibody directed against HDL was obtained from Behringwerke AG (Marburg, Germany). PTFE films were mounted in a 24 well test device ${ }^{20}$ and rinsed twice with phosphate buffered saline (PBS) $(8.2 \mathrm{~g} / / \mathrm{NaCl}$, $3.1 \mathrm{~g} / \mathrm{Na}_{2} \mathrm{HPO}_{4}$. $12 \mathrm{H}_{2} \mathrm{O}, 0.2 \mathrm{~g} / / \mathrm{NaH}_{2} \mathrm{PO}_{4}, 2 \mathrm{H}_{2} \mathrm{O} ; \mathrm{pH} 7.4$, obtained from NPBI, Emmer-Compascuum, The Netherlands). The EIA in brief: after incubation of the PTFE surfaces with $20 \%$ human serum-containing culture medium for $1 \mathrm{~h}$, the wells were rinsed four times with PBS containing $0.005 \%$ ( $\mathrm{V} / \mathrm{v}$ ) Tween-20 (Sigma, St. Louis, MO, USA) and subsequently incubated for $1 \mathrm{~h}$ with a solution of the first antibody directed against HSA, IgG, HDL or Fn, After rinsing with PBS/Tween20 , the wells were incubated for $1 \mathrm{~h}$ with a solution of horseradish peroxidase-labelled second antibody (goatanti-rabbit $(\mathrm{gG})$ and rinsed again. The enzymatic colour reaction was started after incubation with the substrate $\left(\mathrm{H}_{2} \mathrm{O}_{2}\right)$ and leuko dye $\left(3,3^{\prime}, 5,5^{\prime}\right.$-tetramethylbenzidine $)$ solution and after $30 \mathrm{~min}$ this reaction was terminated by adding $2 \mathrm{M} \mathrm{H}_{2} \mathrm{SO}_{4}$. The data, presented as protein adsorption, are mean values obtained from absorbance measurements $(450 \mathrm{~nm})$ of dye solutions generated in four wells of a test device.

\section{Cell adhesion}

Human endothelial cells were isolated from the umbilical vein according to the method of Willems et $a l^{21}$. The cells were routinely cultured for up to three passages in tissue 
culture flasks (Costar Europe, Badhoevedorp. The Netherlands) precoated with partially purified human fibronectin (coproduct obtained during the preparation of Factor VIII concentrate from cryoprecipitate; $(\mathrm{B}$ ) as described by van Wachem et al. ${ }^{22}$. The culture medium consisted of a $1: 1$ mixture of Medium 199 and RPMI 1640 (Gibco Europe, Breda, The Netherlands) containing $20 \%$ pooled human serum derived from 20 healthy male donors, $2 \mathrm{mM} \mathrm{L-glutamine}$ (Merck, Darmstadt, Germany), 100 units $/ \mathrm{ml}$ penicillin, $100 \mu \mathrm{g} / \mathrm{ml}$ streptomycin (both Flow Labs, Irvine, UK) and $4 \mu \mathrm{g} / \mathrm{ml}$ fungizone (Gibco). Endothelial cells were harvested by trypsin treatment $10.05 \%$ trypsin/0.02\% EDTA in PBS; Gibco), after which trypsin was inactivated by adding serumcontaining culture medium to the cell suspension.

Cell adhesion experiments were performed with unmodified and plasma-treated PTFE films and ePTFE, which were mounted in a test device with 12 wells having test surfaces of $1.5 \mathrm{~cm}^{2}$, essentially as described by van Wachem et al. ${ }^{10}$. The test surfaces were kept under hyperfiltrated water until the beginning of the experiment. After rinsing the wells twice with PBS, endothelial cells, resuspended in $20 \%$ human serum-containing culture medium, were seeded into the wells at a density of $60000 / \mathrm{cm}^{2}$. After 1,2 and $6 \mathrm{~h}$, the numbers of adherent cells were determined. Before detaching the cells, the wells were washed with serum-containing culture medium followed by rinsing with culture medium lacking serum. The adherent cells were detached by adding a known volume of trypsin solution and the suspended cells were counted in a Bürker chamber. In all experiments, adhesion of endothelial cells to the reference surface, tissue culture polystyrene (TCPS) (Costar Europe), was also determined.

\section{Cell spreading}

Samples for electron microscopy were fixed with a mixture of $1 \%(\mathrm{v} / \mathrm{v})$ glutaraldehyde (Merck-Succhard, Hohenbrunn, Germany) and $1 \%$ (v/v) formaldehyde (J.T. Baker, Deventer, The Netherlands) in PBS and post-fixed in $3 \%(\mathrm{v} / \mathrm{v})$ glutaraldehyde. The samples were dehydrated through a graded series of ethanol solutions to absolute ethanol, then treated for $5 \mathrm{~min}$ with hexamethyldisilazane (Polysciences, Warrington, PA, USA), dried, and stored desiccated ${ }^{23}$. Samples were sputter-coated with approximately $10 \mathrm{~nm}$ gold (cathode sputtering unit 07.120, Balzers Union Ltd, Liechtenstein). The samples were examined by means of a JSM-35 CF scanning electron microscope (Japan Electron Optics Laboratory, Tokyo, Japan) at $15 \mathrm{kV}$ accelerating voltage and cell spreading was qualitatively interpreted.

\section{RESULTS}

\section{Plasma treatment and contact angles}

PTFE surfaces were modified by plasma treatment using nitrogen or oxygen. Dependent on the treatment time, modified PTFE surfaces were prepared with contact angles $15-57^{\circ}$, versus $94-99^{\circ}$ for unmodified PTFE. Figures $1 a$ and $b$ show a rapid, asymptotic decrease of the contact angle of PTFE surfaces as a function of the treatment time. No substantial differences between the decrease of the contact angles of PTFE films treated either with nitrogen or oxygen plasma were observed. The standard deviations of the mean values of the contact angles in Figure 1 are relatively small, although the means were calculated from contact angles of surfaces from three series of PTFE films which were treated independently.

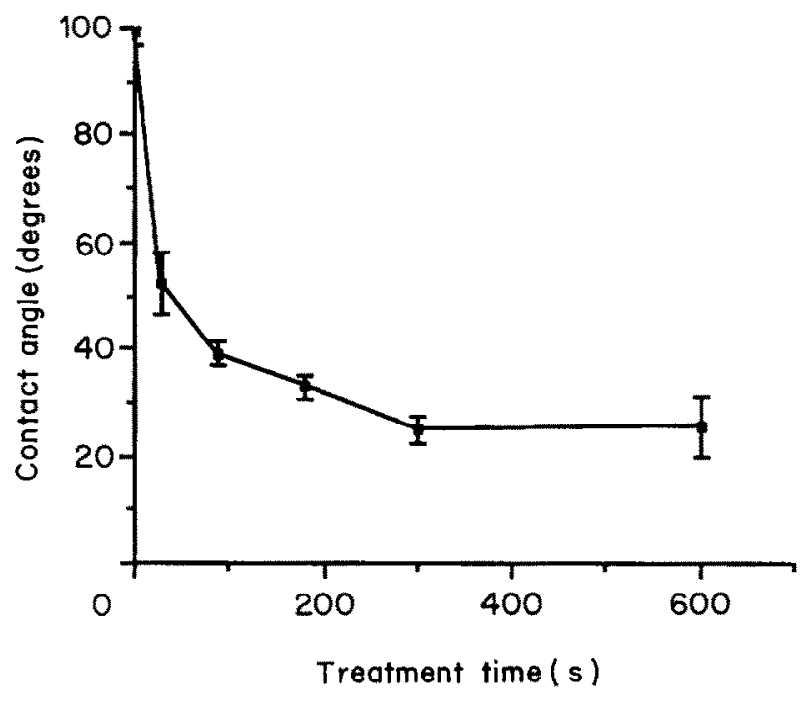

a

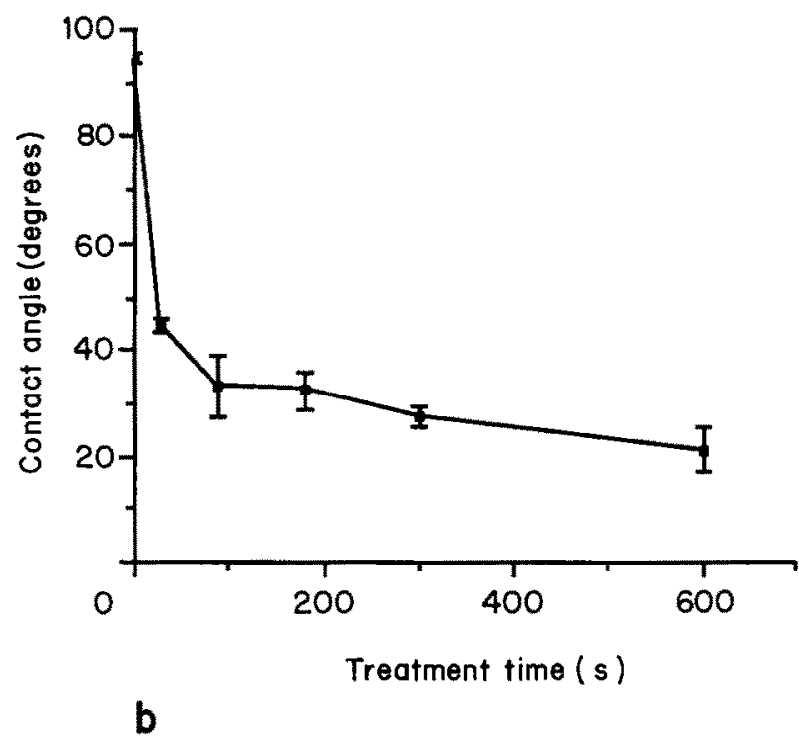

Figure 1 Relationship between contact angle and treatment time of PTFE films modified by means of nitrogen (a) and oxygen (b) plasma. The values are the means of contact angles of three separately modified PTFE films (土standard deviation).

Contact angle measurements at different sites of the PTFE films treated either with nitrogen or oxygen plasma, showed that the contact angles at various places in the central part $(10 \times 10 \mathrm{~cm})$ of the films hardly differed from each other; this was the case for each treatment time (data not shown). These central parts of the PTFE films were used for further experiments.

To obtain a flat surface of ePTFE graft material for contact angle measurements, patches of this material were compressed ( $543 \mathrm{~K} ; 20 \mathrm{MPa}$ ). The mean contact angle of compressed ePTFE material was $104^{\circ}$.

\section{Zeta potential}

The zeta potentials of unmodified and plasma-treated PTFE films are listed in Table 1. Although the plasma treatment of hydrophobic PTFE films resulted in a drastic increase of the wettability, the zeta potential was hardly influenced. Even after a plasma treatment of $600 \mathrm{~s}$ the zeta potential was not much different compared to that of unmodified PTFE. 
Table 1 Contact angles and zeta potentials of untreated and plasma-treated PTFE films

\begin{tabular}{|c|c|c|c|}
\hline Plasma treatment & $\begin{array}{l}\text { Treatment time } \\
\text { (s) }\end{array}$ & $\begin{array}{l}\text { Contact angle } \\
\left({ }^{\circ}\right)\end{array}$ & $\begin{array}{l}\text { Zeta potential } \\
(\mathrm{mV})\end{array}$ \\
\hline- & 0 & $94.1 \pm 1.5$ & $-27.8 \pm 2.5$ \\
\hline Nitrogen & 20 & $54.1 \pm 1.1$ & $-24.3 \pm 0.7$ \\
\hline Nitrogen & 600 & $19.5 \pm 1.3$ & $-29.9+3.9$ \\
\hline Oxygen & 20 & $40.7+0.8$ & $-24.0+0.3$ \\
\hline Oxygen & 600 & $23.2 \pm 3.7$ & $-22.6 \pm 1.3$ \\
\hline
\end{tabular}

Contact angles were determined by means of the captive bubble method ( + standard deviation; $n=3$ ). Zeta potentials were calculated from streaming potential measurements ( \pm standard deviation; $n=3$ ).

\section{ESCA}

Comparison of the C1s spectra of unmodified and plasmatreated PTFE films showed that the spectra changed upon plasma treatment, depending on treatment time and plasma gas (Figures $2 a$ and $b$ ). Compared to the $C 1 \mathrm{~s}$ spectrum of unmodified PTFE, the spectra of the nitrogen plasma-treated PTFE films showed an increased intensity in the binding energy region of 285-289 eV, whereas the spectra of the oxygen plasma-treated PTFE films demonstrated changes in the region of $285-286 \mathrm{eV}$. The intensity in these binding energy regions increased with increasing treatment time. The $\mathrm{C} 1 \mathrm{~s}$ spectra of surfaces treated with one type of plasma (nitrogen or oxygen) were qualitatively the same for the various treatment times.
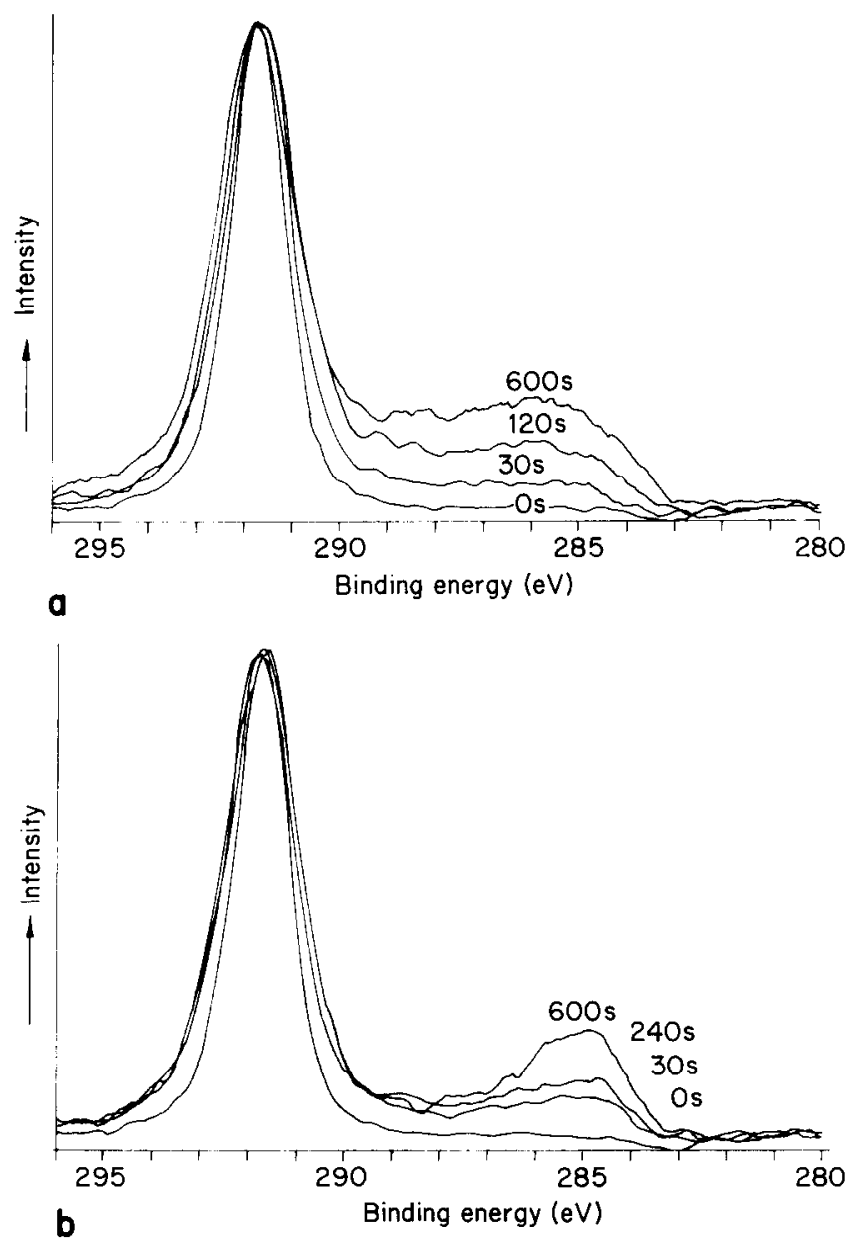

Figure 2 C1s spectra, obtained by ESCA of unmodified and plasmamodified PTFE films (a) nitrogen plasma; (b) oxygen plasma. Treatments with nitrogen and oxygen plasma were performed for the indicated times at 21 and $14 \mathrm{~Pa}$, and 180 and $220 \mathrm{~W}$, respectively. (1) $0 \mathrm{~s}$; (2) $30 \mathrm{~s}$; (3) $120 \mathrm{~s}$; (4) $600 \mathrm{~s}$.
Analysis of detail spectra of the $01 \mathrm{~s}$ and $\mathrm{N} 1 \mathrm{~s}$ region revealed that unmodified PTFE did not have nitrogen- or oxygen-containing groups, but plasma-treated surfaces did contain such groups. The changes in the $\mathrm{C} 1 \mathrm{~s}$ spectra could be related to changes in the detail scans of the $01 \mathrm{~s}$ and $\mathrm{N} 1 \mathrm{~s}$ region (data not shown). The results of quantitative analysis showed that the relative surface concentrations of nitrogenand oxygen-containing groups, after treatment of PTFE films with nitrogen or oxygen plasma, generally increased with increasing treatment time (Figures $3 a$ and $b$ ). Treatment of PTFE surfaces with nitrogen plasma resulted in a timedependent increase in incorporated nitrogen and oxygen. Upon treatment with oxygen plasma a time-dependent incorporation of oxygen occurred. However, the relative surface concentration of nitrogen in the surfaces of PTFE films treated with an oxygen plasma was almost independent of the treatment time. Since the spectra were measured at medium resolution, the surface concentrations of the various elements could not be correctly calculated, but our data indicated that the oxygen and nitrogen concentrations were in general very low compared to the concentrations of carbon and fluorine. After $600 \mathrm{~s}$ treatment with nitrogen plasma, the surface concentrations of oxygen and nitrogen were $\sim 3 \%$, whilst the concentration of oxygen after $600 \mathrm{~s}$
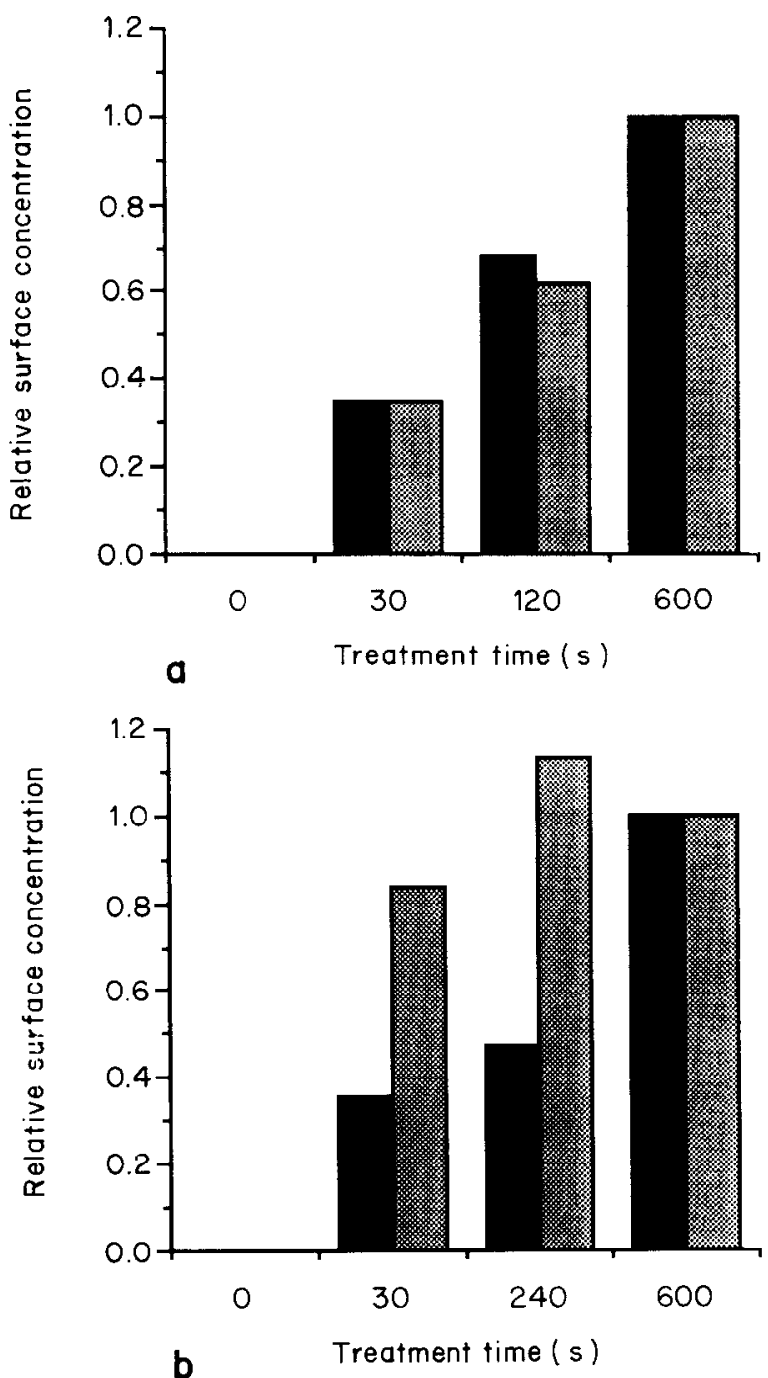

Figure 3 The relative surface concentrations of oxygen and nitrogen after treatment of PTFE films with nitrogen (a) and oxygen (b) plasma for various times. Surface concentrations of oxygen and nitrogen in plasmatreated PTFE films were calculated relative to the concentrations of these elements in films which were treated for $600 \mathrm{~s}$. For further experimental conditions see legend of Figure 2. 
Table 2 The relative concentrations of atomic oxygen, nitrogen and the sum of both $(O+N)$ in the surface of plasma-treated PTFE films after etching with argons ions for various times

\begin{tabular}{lllllr}
\hline Plasma treatment & \multicolumn{2}{c}{ Etching } & $\begin{array}{l}\text { Oxygen } \\
(\%)\end{array}$ & $\begin{array}{l}\text { Nitrogen } \\
(\%)\end{array}$ & $\begin{array}{l}\text { O+N } \\
(\%)\end{array}$ \\
\cline { 2 - 5 } & $\begin{array}{l}\text { Time } \\
(\mathrm{min})\end{array}$ & $\begin{array}{l}\text { Layer* } \\
(\mathrm{nm})\end{array}$ & & & \\
\hline Nitrogen & 0 & 0 & 100 & 100 & 100 \\
Nitrogen & 1 & 0.5 & 8 & 16 & 11 \\
Nitrogen & 2 & 1 & 3 & 8 & 5 \\
Oxygen & 0 & 0 & 100 & 100 & 100 \\
Oxygen & 1 & 0.5 & 18 & 56 & 22 \\
Oxygen & 2 & 1 & 14 & 76 & 21 \\
\hline
\end{tabular}

All surfaces were treated with either nitrogen or oxygen plasma for $600 \mathrm{~s}$ The atomic concentrations were determined by mearls of ESCA and were expressed as percentages of the respective oxygen or nitrogen concentrations before etching. For further experimental details see legend of Figure 2. ${ }^{*}$ It is assumed that the etching rate for PTFE is about the same as for $\operatorname{Ta}_{2} \mathrm{O}_{5}$.

treatment with oxygen plasma was about $5 \%$. However, treatment with oxygen plasma resulted in the incorporation of $<1 \%$ nitrogen.

The thickness of the modified surface layer of plasmatreated PTFE films was determined by etching with $\mathrm{Ar}^{+}$ions at a rate corresponding with $0.5 \mathrm{~nm} / \mathrm{min}$ for $\mathrm{Ta}_{2} \mathrm{O}_{5}$. It is assumed that the etching rate for PTFE is about the same as for $\mathrm{Ta}_{2} \mathrm{O}_{5}$. When $0.5 \mathrm{~nm}$ of the modified surface was removed, most of the incorporated nitrogen and oxygen atoms were also removed (Table 2). The surface modifications induced by treatment with nitrogen plasma were more restricted to the surface than those induced by treatment with oxygen plasma. After etching a layer of $1 \mathrm{~nm}$ from oxygen plasma-treated PTFE films, $20 \%$ of incorporated nitrogen and oxygen atoms was still present in the surface, whilst after etching $1 \mathrm{~nm}$ from nitrogen plasma-treated PTFE films, only $5 \%$ of the incorporated nitrogen and oxygen atoms remained.

\section{Protein adsorption}

The amounts of HSA, HDL and IgG adsorbed from 20\% serum-containing culture medium to plasma-treated PTFE films were much larger than those adsorbed to unmodified PTFE films (Figures $4 a$ and $b$ ). The amounts of adsorbed HSA and HDL to nitrogen and oxygen plasma-treated PTFE films and IgG to surfaces treated with nitrogen plasma were almost independent of the contact angle. The amount of IgG adsorbed to PTFE films treated with oxygen plasma increased with decreasing contact angle.

From serum-containing culture medium, Fn adsorbed to nitrogen or oxygen plasma-treated PTFE films in relatively large amounts compared with unmodified PTFE (Figure 5). Irrespective of the type of plasma treatment, the amounts of Fn adsorbed to treated PTFE films increased slightly with decreasing contact angle.

\section{Cell adhesion}

In Figures $6 a$ and $b$, the results of adhesion of human endothelial cells from $20 \%$ serum-containing culture medium to unmodified and plasma-treated PTFE films are shown. During the first $6 \mathrm{~h}$, endothelial cells hardly adhered to the unmodified PTFE film, whereas relatively large numbers of cells were detected on plasma-treated PTFE films during this period. After $6 \mathrm{~h}$ of incubation, the number of cells adhered to plasma-treated surfaces approximated the number of cells adhered to TCPS. This was most evident for PTFE films with
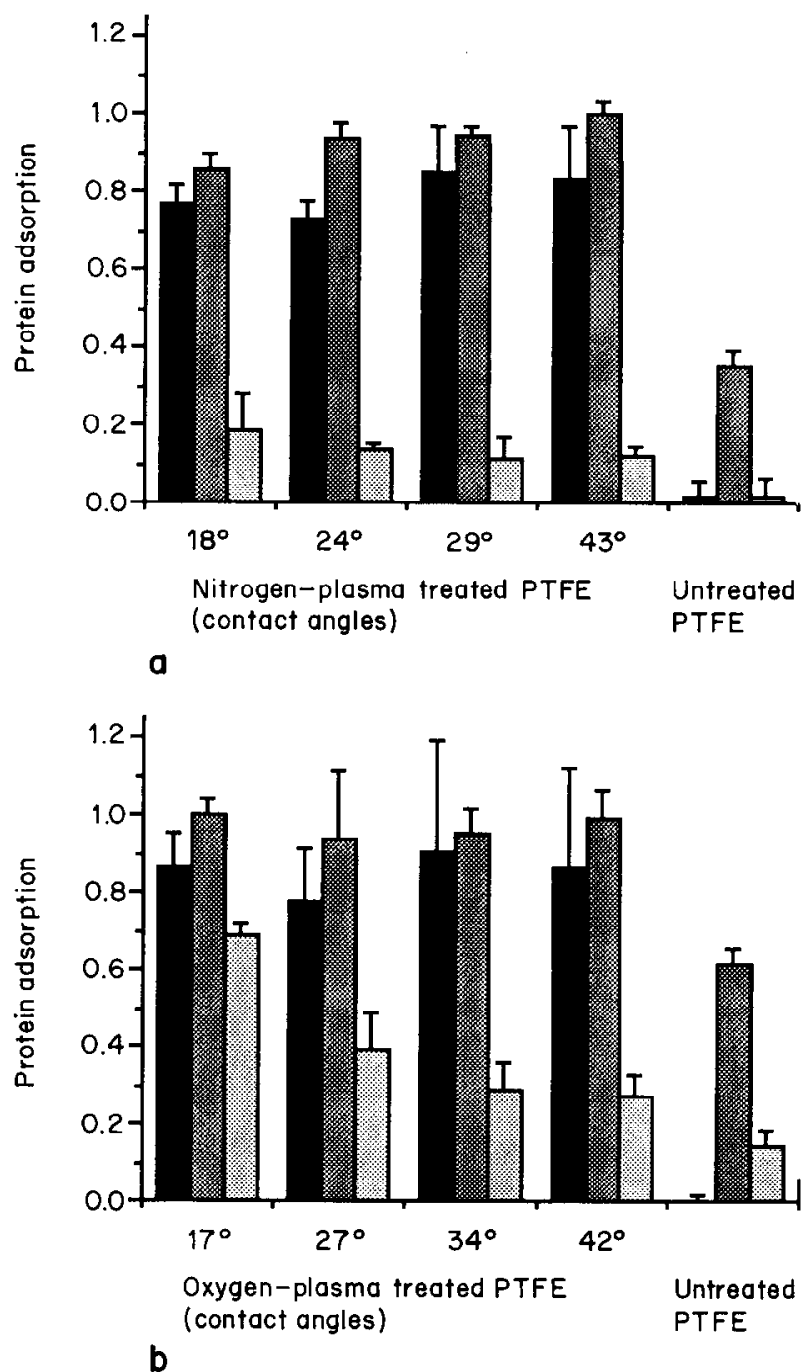

Figure 4 Adsorption of human serum albumin (HSA) $\mathbf{n}$, high-density lipoprotein (HDL) 霠 and immunoglobulin $G(/ g G)$ 圈 to untreated, nitrogen (a) and oxygen (b) plasma-treated PTFE films after $1 \mathrm{~h}$ incubation with $20 \%$ human serum-containing culture medium. The data are mean values of absorbances of dye solutions generated in four wells ( \pm standard deviation).

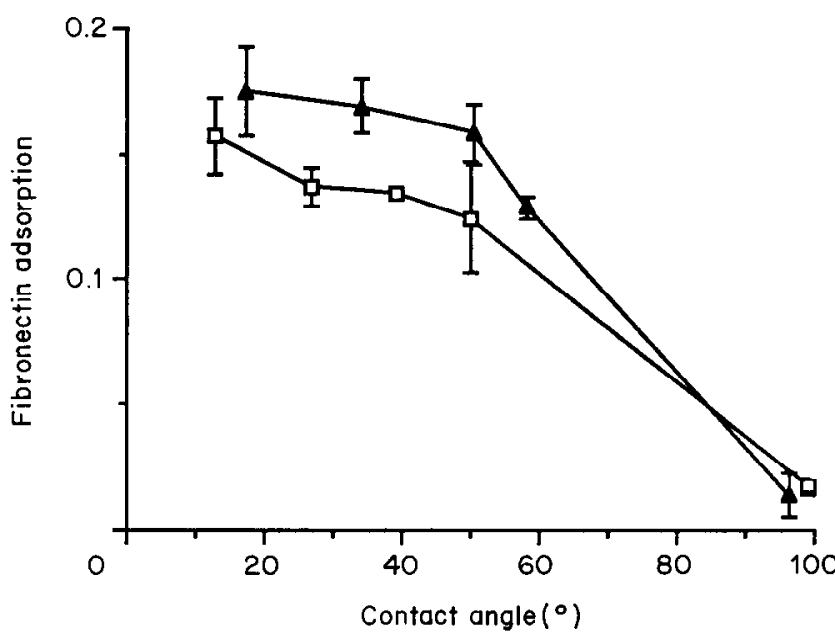

Figure 5 Adsorption of fibronectin to untreated, nitrogen-p/asma, $\square$ and oxygen-plasma, A, treated PTFE films after incubation with $20 \%$ human serum-containing culture medium, as a function of the contact angle of the surfaces before incubation. The data are mean values of absorbances of dye solutions generated in four wells ( \pm standard deviation).

contact angles between 20 and $45^{\circ}$. The number of adherent cells on these films was $90-110 \%$ of the number of cells found on TCPS. For plasma-treated PTFE films with a 

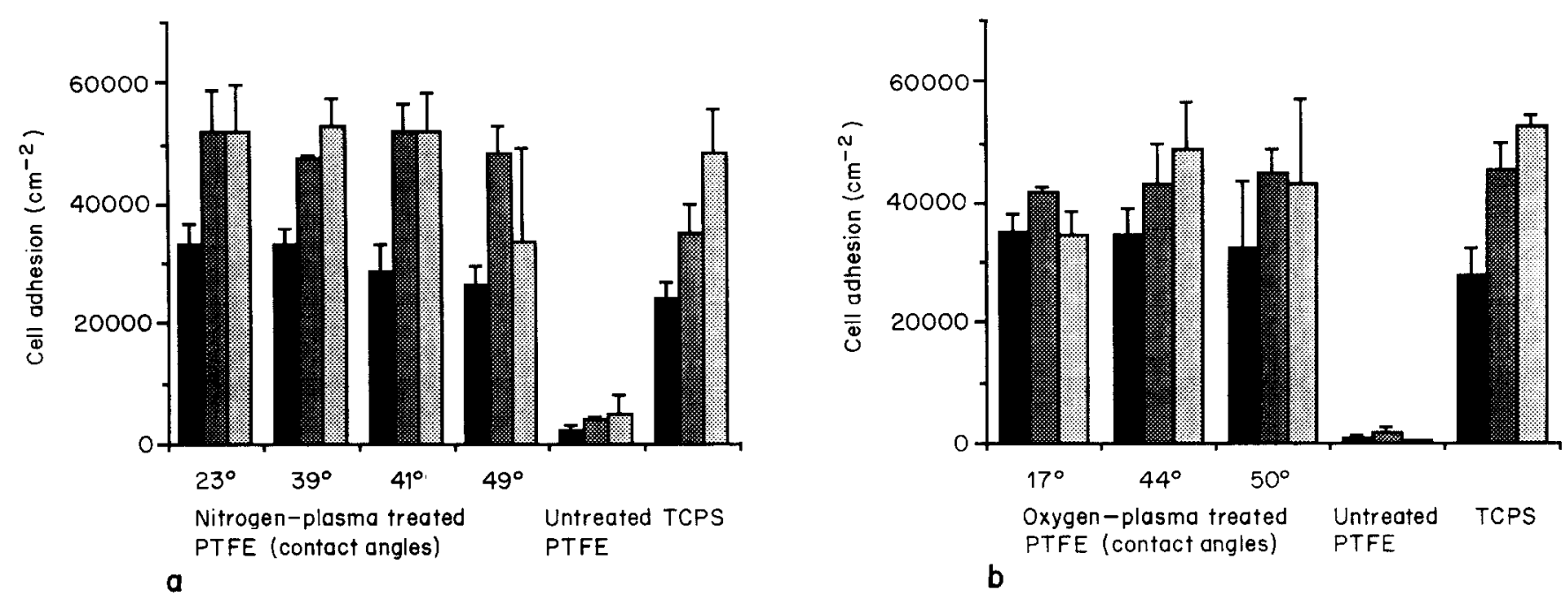

Figure 6 Adhesion of human endothelial cells to untreated, nitrogen (a) and oxygen (b) plasma-treated PTFE films and to TCPS, after incubation with a cell suspension for $1 \mathbf{Q}, 2$ 图 and $6 \mathrm{~h}$, respectively. Cell adhesion is expressed as cells $/ \mathrm{cm}^{2}( \pm$ standard deviation; $\mathrm{n}=3)$.

contact angle $<20 \%$ or $>45^{\circ}$ the adhesion percentage after $6 \mathrm{~h}$ varied from 65 to $85 \%$ compared to TCPS.

To evaluate the effect of plasma treatment on the adhesion of endothelial cells to vascular graft material, ePTFE patches were treated with nitrogen or oxygen plasma for various treatment times (Table 3). The number of endothelial cells adhered to plasma-treated ePTFE surfaces, after $6 \mathrm{~h}$ of incubation with a cell suspension, was considerably larger than the number of cells adhered to unmodified ePTFE and almost equal (92-97\%) to the number of cells found on TCPS.

\section{Cell spreading}

After incubation with cell suspensions for 1,2 and $6 \mathrm{~h}$, no cell spreading was observed on unmodified PTFE films (Figure 7a), whilst cells were completely spread on all plasma-treated PTFE films (Figure 7b). Detachment of spread endothelial cells from modified PTFE films was observed when surfaces with a contact angle $<20^{\circ}$ or $>45^{\circ}$ were used. Incubation of unmodified ePTFE graft material with a suspension of endothelial cells for $6 \mathrm{~h}$ resulted in adhesion of rounded, not well-spread cells (Table 3; Figure 7c). Occasionally, adherent aggregates of cells were observed on this surface. A monolayer of well-spread endothelial cells was formed on plasma-treated ePTFE after $6 \mathrm{~h}$ exposure to a cell suspension (Figure $7 d$ ). This monolayer covered the porous structure of the ePTFE surface.

Table 3 Adhesion and spreading of human endothelial cells on untreated and plasma-treated ePTFE

\begin{tabular}{lcccc}
\hline Plasmatreatment & $\begin{array}{l}\text { Treatment } \\
\text { time } \\
(\mathrm{s})\end{array}$ & \multicolumn{2}{c}{ Cell adhesion } & Cell spreading \\
\cline { 3 - 4 } & & $\begin{array}{l}\text { Absolute } \\
\left(\times 10^{3} / \mathrm{cm}^{2}\right)\end{array}$ & $\begin{array}{l}\text { Relative to } \\
\text { TCPS }(\%)\end{array}$ \\
\hline & 0 & $33.6 \pm 5.7$ & $57.9 \pm 9.8-^{*}$ \\
Nitrogen & 90 & $56.6+1.6$ & $97.4+2.8+^{*}$ \\
Nitrogen & 180 & $54.4+1.9$ & $93.6+3.2++^{* *}$ \\
Oxygen & 210 & $53.9 \pm 1.6$ & $92.7 \pm 2.7+$ \\
Oxygen & 360 & $53.4 \pm 0.8$ & $92.0 \pm 1.3+$ \\
\hline
\end{tabular}

* See Figure $7 c$.

**See Figure $7 d$. Complete spreading of almost all cells $(+)$ or hardly any cells $(-1$. Treatment with nitrogen and oxygen plasma was performed for the indicated times at 21 and $15 \mathrm{~Pa}$ and 180 and $210 \mathrm{~W}$. respectively. Cell adhesion and spreading were determined after $6 \mathrm{~h}$ of incubation. Cell adhesion values are means of three determinations ( + standard deviation).

\section{DISCUSSION}

Since the luminal surface of vascular grafts is not spontaneously overgrown by endothelium, which is the natural lining of a normal blood vessel, seeding of endothelial cells has been proposed to obtain endothelialization. A prerequisite for successful cell seeding is optimal adhesion of endothelial cells to the graft surface. The present study was undertaken to investigate and optimize the adhesion of endothelial cells to PTFE, commonly used for the production of vascular grafts.

It is not clear which surface characteristics determine cell adhesion to polymers and which of them are of primary importance. Several polymer surface characteristics have been proposed, including specific chemical groups ${ }^{24,25}$. interfacial free energy ${ }^{10,26}$ and surface charge ${ }^{27,28}$. Results of studies concerning the influence of these factors on cell adhesion are sometimes contradictory or suggest that yet unknown factors may also play a role. Following the suggestion of van Wachem et al. ${ }^{10}$ that adhesion and proliferation of human endothelial cells are promoted on moderately wettable polymers, we attempted to stimulate the adhesion of endothelial cells by improving the wettability of PTFE surfaces. A series of PTFE films with contact angles of $15-55^{\circ}$ was prepared by means of gas plasma (glow discharge) treatment, to study the effect of wettability on the adsorption of serum proteins and adhesion of endothelial cells. These surfaces were characterized by physical and chemical parameters. Moreover, the adhesion of endothelial cells to plasma-treated, expanded PTFE graft material was studied.

\section{Surface characterization of plasma-treated PTFE films}

Treatment with nitrogen or oxygen plasma was shown to be an efficient method to improve the wettability of hydrophobic PTFE surfaces, which even increased after a short exposure to plasma, allowing us to create surfaces of varying wettability by changing only the treatment time.

Despite the clear effect of plasma treatment on the wettability of PTFE films, the zeta potentials of the surfaces were hardly affected by modification. This indicates that the chemical groups incorporated into the PTFE surface upon plasma treatment are not ionized at neutral $\mathrm{pH}$. The results of endothelial cell adhesion experiments, also performed at neutral $\mathrm{pH}$, revealed a clear effect of plasma treatment on cell 

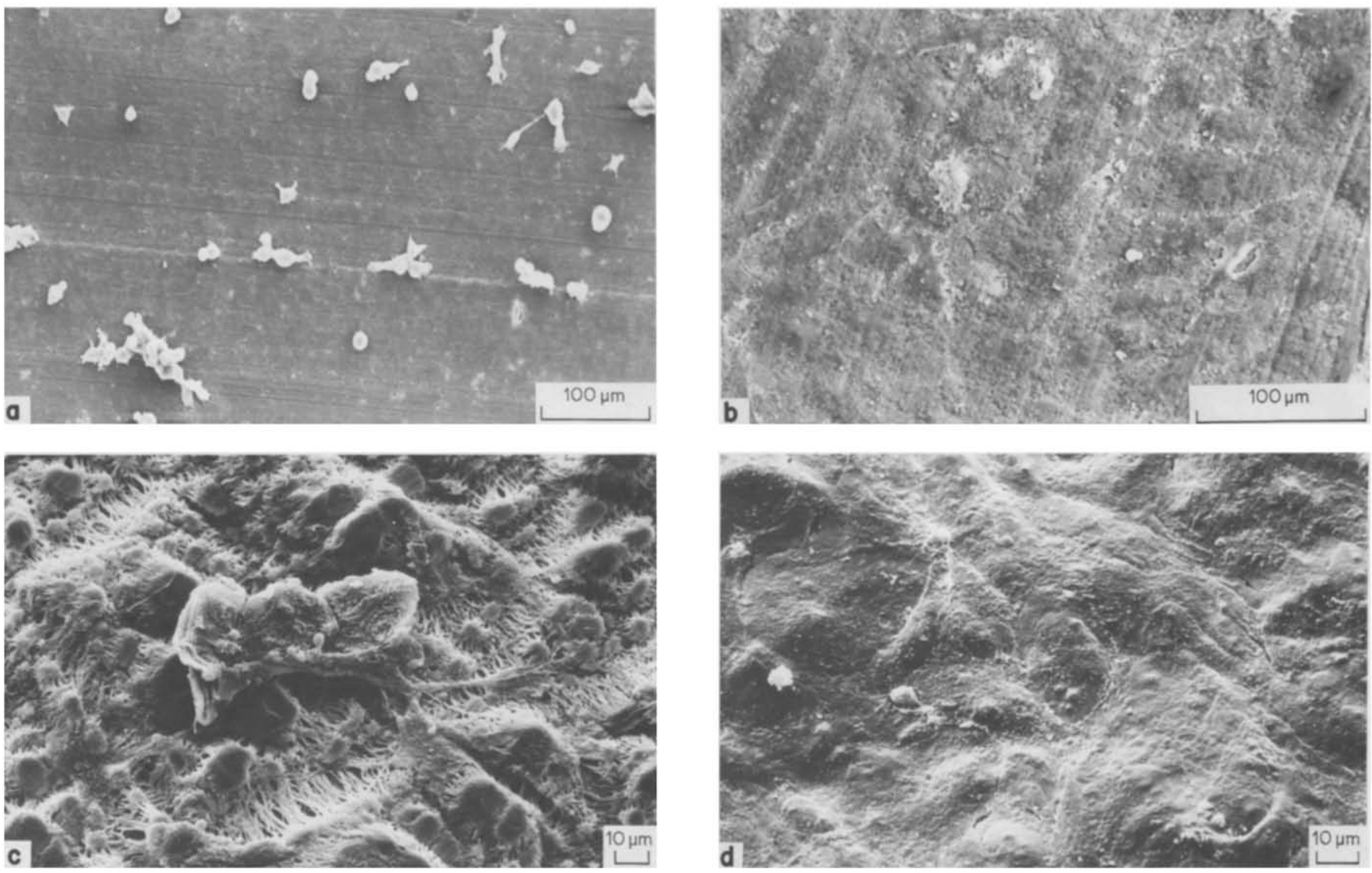

Figure 7 Scanning electron micrographs of endothelial cells adherent to: (a) untreated PTFE; (b) nitrogen plasma-treated (240 s) PTFE; (c) untreated ePTFE; (d) nitrogen plasma-treated (180 s/ ePTFE. All surfaces were incubated with cell suspensions for 6 h. Note the rounded cells in Figures 7 a and c and the flattened, fully spread cells in Figures $7 \mathrm{~b}$ and $\mathrm{d}$

adhesion. Since the zeta potential of PTFE surfaces is hardly affected by plasma treatment, the small differences in surface charge probably do not influence cell adhesion. The unmodified PTFE surfaces had a negative zeta potential, although these surfaces do not contain charged groups. This has also been reported for uncharged polymers like polystyrene and poly(vinyl chloride) ${ }^{18}$ and is probably caused by specific adsorption of ions to the surface.

Neither nitrogen- nor oxygen-containing groups were detected within the surface of unmodified PTFE films by means of ESCA, whereas plasma treatment of PTFE films resulted in the incorporation of nitrogen- and oxygencontaining groups into the surface. The increased wettability of treated PTFE films can be ascribed to this nitrogen and oxygen incorporation for there is a linear relationship between the relative surface concentration of nitrogen and oxygem atoms of treated PTFE films and the contact angle measured at thesc surfaces (data not shown). Nitrogen- and oxygen-containing groups were detected in the surfaces of PTFE treated either by nitrogen or oxygen plasma, which is probably due to a subsequent reaction of atmospheric nitrogen and oxygen with long-living polymer radicals, which are generated in the surface during plasma treatment, since the used gases themselves have a purity of $>99.5 \%$. Ramsayet al. ${ }^{25}$ demonstrated that molecular oxygen is more reactive toward polymer radicals than is molecular nitrogen. This may explain why the oxygen content of the surfaces increased as a function of treatment time when the films were treated with nitrogen plasma, whereas the nitrogen content was very low and did not change during treatment with oxygen plasma.

Comparison of the C1s spectra of unmodified PTFE with those of PTFE films which were treated with the same plasma gas revealed that the spectra alteration depended on treatment time, whilst the changes were qualitatively the same. However, ESCA spectra of the $C 1$ s region of modified PTFE surfaces showed qualitative differences in films treated with nitrogen and oxygen plasma. These results suggest that, irrespective of the treatment time, the same modification processes occur when a particular plasma gas is used, but that these processes are somewhat different for nitrogen and oxygen plasma.

Etching experiments during ESCA measurements showed that plasma treatment of PTFE films resulted in a very superficial modification of the surface $(\sim 1 \mathrm{~nm})$. This superficiality is of importance with regard to modification of ePTFE vascular grafts to improve adhesion of endothelial cells, because such a modification should not affect the porosity and the mechanical properties of the graft.

\section{Adsorption of serum proteins and endothelial cell adhesion to plasma-treated PTFE}

The adsorption of HSA, HDL and IgG from 20\% human serum-containing culture medium to plasma-treated PTFE films was increased compared to unmodified PTFE films. These results are comparable to those of van Wachem et al. ${ }^{19}$ who demonstrated that these proteins adsorbed in relatively large amounts from $20 \%$ serum-containing medium to TCPS (contact angle within the range of those of the modified PTFE surfaces), compared to the hydrophobic material fluoroethylenepropylene (FEP) copolymer with a contact angle similar to that of unmodified PTFE. The amounts of fibronectin adsorbed to modified PTFE surfaces were also larger than the amount adsorbed to unmodified PTFE. Similar observations have been reported by others who 
determined fibronectin adsorption to hydrophilic and hydrophobic substrates by means of immunological and radiolabelling techniques ${ }^{19,29,30}$. The relaively large amounts of fibronectin adsorbed to plasma-treated PTFE surfaces from culture medium containing $20 \%$ human serum compared to untreated PTFE strongly suggests that these modified surfaces have a high affinity for cellular fibronectin ${ }^{19}$.

Adhesion of human endothelial cells to plasma-treated PTFE films was strongly enhanced compared to unmodified films. This effect was irrespective of the gas used to generate a plasma. These results are in agreement with those of other investigators, who also found an increased adhesion of cells to more hydrophilic surfaces, obtained by plasma treatment of polymers, compared to unmodified polymers ${ }^{29} 31-33$. The adhesion of endothelial cells after $6 \mathrm{~h}$ incubation to modified PTFE surfaces showing a contact angle between 20 and $45^{\circ}$ was comparable with cell adhesion to TCPS, which is known for its excellent cell adhesion properties ${ }^{10}$. Modified PTFE surfaces with a contact angle smaller or larger than those of this range also showed increased cell adhesion, compared to unmodified PTFE surfaces, but the numbers of adherent cells were fewer than found on TCPS after $6 \mathrm{~h}$ incubation.

Plasma treatment of PTFE does not only lead to an increased number of adherent endothelial cells, but also to a pronounced morphological change of these cells. Endothelial cells were well spread on plasma-treated PTFE films after all cell incubation periods, but cells adherent to unmodified PTFE were hardly spread. Modified PTFE surfaces outside the contact angle range of $20-45^{\circ}$ sometimes showed detachment of cells, especially after $6 \mathrm{~h}$ of incubation. The optimal spreading of endothelial cells on modified PTFE surfaces showing contact angles within the range of $20-45^{\circ}$, strongly suggests that endothelial cells are able to proliferate on these surfaces ${ }^{10}$.

Adhesion and spreading on plasma-treated PTFE films was promoted, although a relatively large amount of proteins (lgG, HDL, HSA) adsorbed to these surfaces, which are known to inhibit cell adhesion ${ }^{19}$. On the contrary, cell adhesion was absent on untreated PTFE, whilst fewer adhesion-inhibiting proteins adsorbed to untreated PTFE. An explanation of these phenomena may be given in terms of displacement of adsorbed serum proteins by cellular fibronectin.

Endothelial cells require extracellular matrix compounds such as fibronective for optimal adhesion and spreading. Since relatively small amounts of fibronectin adsorb from $20 \%$ serum-containing medium to plasma-treated PTFE and almost no fibronectin adsorbs to unmodified PTFE (Figure 5), endothelial cells have to deposit their own cellular fibronectin for adhesion and spreading ${ }^{34}$. However, when endothelial cells are seeded from serum-containing medium, serum proteins such as IgG, HDL and HSA will irreversibly adsorb to the hydrophobic unmodified PTFE ${ }^{35,36}$. These irreversibly adsorbed proteins will not be displaced by cellular fibronectin, preventing optimal adhesion and spreading of endothelial cells $^{37}$. Exchange of adsorbed serum proteins with cellular fibronectin will be possible on more hydrophilic surfaces ${ }^{35}, 36$. Plasma-treated surfaces with contact angles of $20-45^{\circ}$ most probably allow the displacement of adsorbed serum proteins by fibronectin secreted by the cells ${ }^{37}$. PTFE surfaces with contact angles $<20^{\circ}$ probably show completely reversible protein adsorption and the interaction of adsorbed fibronectin with the surface is too weak to support optimal cell adhesion and spreading.

According to van Wachem et al. ${ }^{10}$ endothelial cell adhesion is optimal to moderately water-wettale polymers, which show a contact angle of about $40^{\circ}$. From the results of the present study, we assume that the adhesion process is not exclusively governed by the wettability of the surfaces, but also by chemical characteristics. None of the unmodified polymers studied by van Wachem et al. ${ }^{10}$, including those which are moderately wettable, supported complete spreading of endothelial cells. Fully spread cells were only seen on TCPS and tissue culture poly(ethylene terephthalate) (TCPET). Cellulose-2.5-acetate differs by only $4^{\circ}$ in contact angle from TCPS; nevertheless, the number of adherent cells was $<30 \%$ compared to the number of cells on TCPS. In our study, and in that of van Wachem et al. ${ }^{10}$ optimal adhesion and spreading was only observed on gas plasma-treated surfaces like TCPS, TCPET and modified PTFE. Recently Pratt et al. ${ }^{32}$ showed that treatment of TCPET with air plasma also enhanced the adhesion of human adult endothelial cells.

The foregoing suggests that plasma treatment of polymers introduces specific chemical groups into the surface, which not only increase the wettability of the surface, but which also have a specific effect on the interaction of endothelial cells with the surface. The surfaces of plasma-treated polymers, including TCPS ${ }^{29,32}$ (and unpublished ESCA data, Costar Europe) as well as our treated PTFE surfaces, are enriched in oxygen and nitrogen (Figure 3). It is likely that oxygen-and/or nitrogen-containing groups are involved in making the surface optimal for endothelial cell adhesion and spreading.

In view of the beneficial effects described of plasma treatment of PTFE films on the adhesion and spreading of human endothelial cells, it is logical to study the possibility of modifying Teflon vascular grafts (ePTFE; GORE TEX) in the same way. The contact angle of compressed ePTFE graft material, which was about $100^{\circ}$, indicated that this material had not been surface-treated by the manufacturer. Treatment of expanded PTFE patches with oxygen or nitrogen plasma improved adhesion and spreading of endothelial cells, compared to unmodified patches. Adhesion of endothelial cells to the modified graft material was comparable with adhesion to TCPS, which indicates the feasibility of plasma modification of ePTFE to improve endothelial cell adhesion. The difference in cell adhesion between modified and unmodified PPTFE patches was not as large as that observed in adhesion experiments with modified and unmodified PTFE films. This is probably due to the porous structure of the surface of ePTFE patches, which allows the cells to attach to the unmodified material. Scanning electron micrographs confirmed this, since attachment of aggregates of endothelial cells to the unmodified graft surface was observed. This phenomenon has never been observed on unmodified PTFE films. Though the surface of the ePTFE graft material is porous (internodal distance $22 \mu \mathrm{m}$ ), endothelial cells spread completely on the plasma-treated graft material and covered the pores. Cell spreading on the modified ePTFE patches was much like the spreading of endothelial cells on the luminal surface of a preclotted ePTFE graft, used in canine experiments ${ }^{38,39}$.

In conclusion, the present study shows that treatment of PTFE with nitrogen or oxygen plasma improves the wettability of the surface by introducing nitrogen- and oxygen-containing groups into the surface. Adhesion of human endothelial cells from serum-containing culture medium to these plasma-treated surfaces is comparable to cell adhesion to TCPS. Plasma treatment of ePTFE vascular graft material makes the surface optimal for the in vitro adhesion of human endothelial cells. This is promising in view of endothelial cell seeding into ePTFE vascular grafts for use in humans. 


\section{ACKNOWLEDGEMENTS}

We thank Mr L. Terlingen for his help during the ESCA measurements, and Drs G. van der Sluijs and I. Vermes from the Medisch Spectrum Twente Hospital, Enschede, The Netherlands, for their support, and the obstetric staff of this hospital for the supply of umbilical cords.

\section{REFERENCES}

1 Callow, A.D., Historical overview of experimental and ctinical development of vascular grafts, in Biological and Synthetic Vascular Prostheses (Eds J.C. Stantey, W.E. Burkel, S.M. Lindenauer, R.H. Bartlett and J.G. Turcotte), Grune and Stratton, New York, USA, 1982, p. 11

2 Herring, M.B., Endothelial seeding of blood flow surfaces, in Vascular Grafting, Clinical Applications and Techniques (Ed. C.B. Wright). John Wright PSG Inc., Boston, USA, 1983, p. 275

3 Berger, K., Sauvage, L.R., Rao, A.M. and Wood, S.J., Healing of arterial prostheses in man: its incompleteness, Ann. Surg. 1972, 175, 118

4 Stanley, J.C., Burkel, W.E., Graham, L.M. and Lindblad, B., Endothelial cell seeding of synthetic vascular prostheses, Acta Chir. Scand. Suppl. $1985,529,17$

5 Herring, M., Gardner, A. and Glover, J., Dacron femoral-popliteal bypass grafts seeded with mechanically derived endothelium: an update, $A S A / O$ J. 1985,8 (2), 74

6 Ortenwall, P.. Wadenvik, H., Kutti. J. and Risberg. B., Reduction in deposition of Indium 111 -labeled platelets after autologous endothelial cell seeding of dacron aortic bifurcation grafts in humans: a preliminary report, J. Vasc. Surg. 1987, $6(1), 17$

7 Graham, L.M., Stanley, J.C. and Burkel, W.E., Improved patency of endothelial-cell-seeded, long, knitted Dacron ${ }^{\oplus}$ and ePTFE vascular prostheses, ASAIO J. 1985, 8 (2), 65

8 Burkel, W.E., Ford, J.W. Vinter, D.W., Kahn, R.H., Graham, L.M. and Stanley, J.C.. Endothelial seeding of enzymatically derived and cultured cells on prosthetic grafts, in Biological and Synthetic Vascular Prostheses (Eds J.C. Stanley, W.E. Burkel, S.M. Lindenauer, R.H. Bartlett and J.G. Turcotte), Grune and Stratton, New York, USA, 1982, p. 631

9 Graham, L.M., Burkel, W.E., Ford, J.W., Vinter, D.W., Kahn, R.H. and Stanley, J.C., Expanded polytetrafluoroethylene vascular prostheses seeded with enzymatically derived and cultured canine endothelial cells, Surgery 1982, 91 (5) 550

10 van Wacham, P.B., Beugeling, T., Feijen, J., Bantjes, A., Detmers, J.P. and van Aken, W.G., Interaction of cultured human endothelial cells with polymeric surfaces of different wettabilities, Biomaterials 1985 . 6, 403

11 Ramalanjaona, G., Kempczinski, R.F., Rosenman, J.E., Douville, E.C. and Silberstein, E.B., The effect of fibronectin coating on endothelial cell kinetics in polytetrafluoroethylene grafts, J. Vasc. Surg. 1986. 3 (2), 264

12 Seeger, J.M. and Klingman, N., Improved in vivo endothelialization of prosthetic grafts by surface modification with fibronectin, $J$. Vasc. Surg. $1988,8(4), 476$

13 Kempczinski, R.F., Douville, E.C., Ramalanjaonia, G., Ogle, J.D. and Silberstein, E.B., Endothelial cell seeding on a fibronectin-coated substrate, in Endothelial Seeding in Vascular Surgery, (Eds M. Herring and J.L. Glover), Grune and Stratton, Orlando, Florida, USA, 1987, p. 57

14 Allen, B.T., Long, J.A., Clark, R.E., Sicard, G.A., Hopkins, K.T. and Welch, M.J., Influence of endothelial cell seeding on platelet deposition and patency in small-diameter Dacron arterial grafts, $J$. Vasc. Surg. 1984. 1 (1), 224

15 Dekker, A., Poot, A., Beugeling, T., Bantjes, A. and van Aken, W.G., The effect of vascular cell seeding on platelet deposition in an in vitro capillary perfusion model, Thromb. Haemost. 1989, 61 (3), 402

16 Andrade, J.D., Smith, L.M. and Gregonis, D.E., The contact angle and interface energetics, in Surface and Interfacial Aspects of Biomedical Polymers Volume 1, Surface chemistry and physics, (Ed. J.D. Andrade), Plenum Press, New York, USA, 1985, p. 249

17 van Wagenen, R.A. and Andrade, J.D. Flat plate streaming potential investigations: Hydrodynamics and electrokinetic equivalency, $J$. Colloid. Interface Sci. 1980, 76 (2), 305

18 van Wagenen, R.A., Coleman, D.L., King, R.N., Triolo, P., Brostrom, L., Smith, L.M., Gregonis, D.E. and Andrade, J.D., Streaming potential investigations: Polymer thin films, J. Colloid. Interface Sci. 1981, 84 (1) 155

19 van Wachem, P.B., Vreriks, C.M., Beugeling, T., Feijen, J., Bantjes, A., Detmers, J.P. and van Aken, W.G., The influence of protein adsorption on interactions of cultured endothelial cells with polymers, $J$. Biomed. Mater. Res. 1987, 21, 701

20 Poot, A., Beugeling, T., van Aken, W.G. and Bantjes, A., Detection of surface-adsorbed (lipo)proteins by means of a two step enzymeimmunoassay: A study on the Vroman effect, J. Biomed. Mater. Res. 1990, 24, 1021

21 Willems, Ch., Astaidi, G.C.B., de Groot, Ph.D., Jansen, M.C., Gonsalves, M.D., Zeijlemaker, W.P., van Mourik, J.A. and van Aken, W.G., Media conditioned by cultured vascular endothelial cells inhibit the growth of vascular smooth muscle cells, Exp. Cell Res. 1982, 139, 191

22 van Wachem, P.B., Reinders, J.H., van Buul-Wortelboer, M.F., de Groot, Ph.G., van Aken, W.G. and van Mourik, J.A., Von Willebrand factor in cultured human vascular endothelial cells from adult and umbilical cord arteries and veins, Thromb. Haemost. 1986, 56, 189

23 Nation, J.L., A new method using hexamethyldisilazane for preparation of soft insect tissues for scanning electron microscopy, Stain Technology 1983, 58 (6). 347

24 Lydon, M.J., Minett, T.W. and Tighe, B.J., Cellular interaction with synthetic polymer surfaces in culture, Biomaterials $1985,6,396$

25 Ramsay, W.S., Hertl, W., Nowlan, E.D. and Binkowski, N.J., Surface treatments and cell attachment, In Vitro 1984, 20 (10), 802

26 Absolom, D.R., Hawthorn, L.A. and Chang, G., Endothelialization of polymer surfaces, J. Biomed. Mater. Res, 1988, 22, 271

27 Hatton, S., Andrade, J.D., Hibbs Jr, J.B., Gregonis, D.E. and King, R.N. Fibroblast cell prolieration on charged hydroxyethyl methacrylate copolymers, J. Colloid, Interface. Sci. 1985, 104, 73

28 van Wacham, P.B., Hogt, A.H., Beugeling, T., Feijen, J., Bantjes, A. Detmers, J.P. and van Aken, W.G., Adhesion of cultured human endothelial cells onto methacrylate polymers with varying surface wettability and charge, Biomaterials 1988, 8, 323

29 Chinn, J.A., Horbett, T.A., Ratner, B.D., Schway, M.B., Haque, Y. and Hauschka, S.D., Enhancement of serum fibronectin adsorption and the clonal plating efficiencies of swiss mouse 3T3 fibroblast and MM14 mouse myoblast cells on polymer substrates modified by radiofrequency plasma deposition, $J$. Colloid. Interface Sci. 1989 , 127, 67

30 Chilkoti, A., Ertel, S.I., Ratner, B.D., Horbett, T.A. and Briggs, D., Acetone-N2 glow discharge modified surfaces: investigation of surface chemistry, protein adsorption, and endothelial cell growth, Transactions Fifteenth Annual Meeting of the Society for Biomaterials 28/4-2/5 1989, Vol. XII, Lake Buena Vista, Florida, USA, p. 99

31 van Wachem, P.B. Interactions of cultured human endothelial cells with polymeric surfaces, PhD Thesis, University of Twente, Enschede, The Netherlands, 1987 , p. 39

32 Pratt, K.J., Williams, S.K. and Jarrell, B.E., Enhanced adherence of human adult endothelial cells to plasma discharge modified polyethylene terephthalate, J. Biomed. Mater. Res. 1989, 23, 1131

33 Klee, D., Breuers, W., Bilo-Jung, M., Mittermayer, C. and Hocker, H. Modifizierung von polymeroberflachen zur erhohung der zelladhäsion. Die Angewandte Makromolekulare Chemie 1989, 166/167, 179

34 van Wachem, P.B., Mallens, B.W.L., Dekker, A., Beugeling, T., Feijen, J., Bantjes, A., Detmers, J.P. and van Aken, W.G., Adsorption of fibronectin derived from serum and from human endothelial cells onto tissue culture polystyrene, J. Biomed. Mater. Res. 1987, 21, 1317

35 Feijen, J., Beugeling, T., Bantjes, A. and Smit Sibinga, C.Th., Biomaterials and interfacial phenomena, in Advances in Cardiovascular Physics 3 (Ed. D.N. Ghista), S. Karger, Basel, Switzerland, 1979, p. 100

36 Brash, J.L., Mechanism of adsorption of proteins to solid surfaces and its relationship to blood compatibility, in Biocompatible Polymers, Metals and Composites (Ed. M. Szycher), Technomic, Lancaster. Pennsylvania, USA, 1983, p. 35

37 Dekker, A., Beugeling, T., Wind, H., Poot, A., Bantjes, A., Feijen, J. and van Aken, W.G. Deposition of cellular fibronectin and desorption of human serum albumin during adhesion and spreading of human endothelial cells on polymers, J. Mater. Sci: Materials in Medicine (in press)

38 Plate, G., Hollier, L.H., Fowl, R.J., Sande, J.R. and Kaye, M.P., Endothelial seeding of venous prostheses, Surgery 1984, 96 (5), 929

39 Pearce, W.H., Rutherford, R.B., Whitehill, T.A., Rosales, C., Belf, K.P., Patt, A. and Ramalanjaona, G., Successful endothelial seeding with omentally derived microvascular endothelial cells, J. Vasc. Surg. 1987,5 (1), 203 